\title{
ЖАНРОВІ МОДИФІКАЦЇ̈ РОМАНУ (НА МАТЕРІАЛІ ТВОРІВ В. ФОЛКНЕРА І ВаЛ. ШЕВЧУКА)
}

\begin{abstract}
Боднар О. Б. Жанрові модифікації роману (на матеріалі творів В. Фолкнера і Вал. Шевчука).

У статті проведено компаративне дослідження творів Вільяма Фолкнера «Зійди, Мойсею» і Валерія Шевчука «Привид мертвого дому». Доведено їхню типологічну близькість і водночас художню оригінальність. Показано реалізацію життєвих подій у своєрідній жанровій формі роману, де цілісність створюється не так завдяки наскрізному сюжетові, як передусім у вільному розвитку спільної теми та об'єднавчої ідеї.

Ключові слова: жанр, роман в оповіданнях, новела, художня своєрідність.
\end{abstract}

Боднар О. Б. Жанровые модификации романа (на материале произведений У. Фолкнера и Вал. Шевчука).

В статье проведено компаративное исследование произведений Уильяма Фолкнера «Сойди Мойсей» и Валерия Шевчука «Призрак мертвого дома». Доказывается их типологическая близость и одновременно художественная оригинальность. Показывается реализация жизненных событий в своеобразной жанровой форме романа, где целостность создается не благодаря сквозному сюжету, а прежде всего в свободном развитии общей темы и объединительной идеи.

Ключевые слова: жанр, роман в рассказах, новелла, художественное своеобразие.

Bodnar O. B. Genre modification of a novel (based on the material of W. Faulkner and V. Shevchuk works).

The article deals with a comparative research of William Faulkner «Go down Moses» and Valeriy Shevchuk «Pryvyd Mertvoho Domu» («The Ghost of the Dead House»). Their typological similarity and at the same time art originality were grounded. There was demonstrated the realization of life events into special genre form in which the unity was created not owing to penetrating plot but first of all in free development of common theme and uniting idea.

Key words: genre, novel in stories, novella, art originality.

Твори В. Фолкнера і Валерія Шевчука об'єднує моральнофілософський пафос. Моральне змужніння особистості, пошук правди, вищої від усіх тих сил, що роз'єднують людське суспільство, досліджено в обох письменників за допомогою нової форми роману, де цілісність створюється не тільки через сюжет, а передусім вільним розвитком спільної теми та ідей, що можуть часами входити в 
глибину, а попри все звучать у всьому творі контрапунктом. Цю форму роману називають романом в оповіданнях. Ми подаємо назву роман в оповіданнях, оскільки в оригіналі англійською це звучить «novel in stories».

Листування 3 літературним критиком Малкольмом Каулі, 3 видавцями, інтерв'ю свідчать, що форма роману в оповіданнях особливо зацікавила В. Фолкнера. Крім нього, цей жанр культивували Ш. Андерсен («Уайнсбург Огайо»), Дж. Джойс («Дублінці»), Е. Гемінгвей («У наш час») та ін.

Перші спроби створити роман «Зійди, Мойсею» можна простежити в новелах ще 30-х років. Пізніше постав задум подати цикл оповідок, які розкривали б дві важливі теми - невільництво негрів і безоглядності щодо природи на прикладі одного роду 3 Півдня. Р. Доценко зазначав, що «з невеликої суто мисливської оповідки виріс до розмірів повісті загальновизнаний нині шедевр Фолкнера «Ведмідь». Українським читачам ця новела досі була відома у скороченому варіанті (у збірнику «Червоне листя», 1978), без четвертого розділу; це надавало повісті, якщо читати іiі окремо, більшої стрункості, однак для композиційної й ідейної цілісності всієї книги IV розділ вирішально вагомий» [1, с. 507].

Фолкнер передбачував книгу «Зійди, Мойсею» романом в оповіданнях. Так, у листі до Каулі писав: «Для зібрання оповідань загальна оформленість і зв'язність так само важливі, як і для роману: тобто має бути визначена цілісність, єдиний настрій, розвиток, рух до однієї мети, фіналу» [2, с. 197].

У житті Фолкнера стався симптоматичний збіг обставин. Другий раз у житті він побачився з Андерсеном, і як завше в потрібну хвилю. Уперше йому не були потрібні поради, які він вислуховував п’ятнадцять літ потому в Новому Орлеані. Щось символічне було в тому, що знову на шляху південноамериканського письменника зустрівся метр саме в ту пору, коли Фолкнер обдумував можливість того самого гібридного жанру, який так вдало застосував Андерсен.

Задум почав утілюватися в життя ще з березня 1935 року, коли він опублікував оповідання «Лев» - цікавий сюжет із життя людини на полюванні: молодик повертається в край, де отримав колись бойове хрещення, і з сумом спостерігає, як усе навколо змінилося: ліс став дуже рідким, його перерізала залізниця, і тільки в пам'яті зберігався 
прадавній чарівний пейзаж. В оповіданні автор не зробив жодного відкриття, бо ще не знав, що той психологічний епізод стане частиною новели «Ведмідь», а вона, своєю чергою, стане центральною ланкою роману.

П'ять років по тому В. Фолкнер протягом місяця написав три оповідання: «Судилище», «Не все те золото» («Gold is Not Always'), «Домашнє вогнище» («The Fire and the Hearth») - письменник навіть не підозрював, що, об'єднавшись, ці оповідання стануть главою того ж роману.

Лише в квітні 1940 р. задум роману в оповіданнях більш-менш окреслився. Фолкнер писав у «Рендом Хаус»: «Я зараз роздумую над книгою у стилі «Непереможених», але розділи, які я накидав i спробував десь прилаштувати у вигляді окремих оповідань, були відхилені. А часу переробляти їх у мене немає» [2, с. 137].

Через місяць письменник знову повернувся до цього задуму, відіслав своєму літературному агентові чотири оповідання про чорних, плануючи написати ще два чи три і створити нову книгу. У липні 1940 року Фолкнер завершив оповідання, назву якого «Зійди, Мойсею» дав цілій книзі. Єдність цієї книги літературна критика відчула в тому, що всі, крім одного, оповідання циклу висвітлюють майже півторавікову історію роду Маккаслінів, зокрема й білої та чорної його паростей. «Старий Маккаслін», якого вважають засновником роду, у 30-х роках XIX сторіччя оселився у Міссісіпі, почав володіти плантацією i рабами. Рід «старого Маккасліна» розростався. Його нащадки - дочка і двоє братів-близнят Едмондс (на прізвиська Кумпан) - неодружений і бездітний, та Теофілес (на прізвисько Ферт), у якого 1876 року народився єдиний син Айк (головний герой роману). Від дочки старого Маккасліна пішла жіноча лінія роду: його правнук Маккаслін Едмондс або Івас (що став за рідного батька передчасно осиротілому Айкові), син Маккасліна Едмондса - Закері (Зак) і син Закері - Керазерс (Раз).

Старий Маккаслін мав i незаконних нащадків, які стали результатом його співжиття 3 негритянками-рабинями: від Юніс він мав дочку Томасіну (Томі), а від Томі - сина Террела (Терла). Із шістьох дітей Террела, одруженого із Тенні Бічем, вижило троє Джеймс, або «Джім тітки Тенні» (його онучка, що виросла вже на Півночі, полюбила Керазерса Едмондса й народила від нього сина),

๑ С О. Б. Боднар, 2015. 
Софонсіба і Лукас (онук якого, Семюел, стає вбивцею).

Ми так докладно зупинилися на прокресленні родоводу, аби туттаки застерегти, що сюжет роману в оповіданнях не зводиться лише до родинної хроніки. Його проблематика охоплює не тільки усвідомлення роду як сім'ї. Вона $є$ основним грунтом душевних колізій та центральною соціальною структурою, яка їх породжує. Не дивно, що критики, які цікавляться родовими стосунками, в основному здійснюють психоаналіз. За Каролін Портер: «Критики вийшли на психоаналіз як один із найкращих наявних теоретичних інструментів і моделей у розумінні сучасної ситуації англоєвропейських відносин, що є важливим рушієм у побудові родової ідентичності» [4, с. 169].

Проблематика роману «Зійди, Мойсею» охоплює також історію південноамериканського рабства, що стало психологічним комплексом для Південної Америки, і проблему взаємин людини i природи.

Українські читачі могли знайомитися з романом в оповіданнях В. Фолкнера у спільному перекладі В. Корнієнка і Р. Доценка під назвою «Домашне вогнище», що вийшов друком у видавництві «Молодь» 1983 року. До структури твору входять оповідання: «Було колись» («Was»), «Домашнє вогнище» («The Fire and the Hearth»), «Чорний блазень» («Pantaloon in Black»), «Давні люди» («The Old People»), новела «Ведмідь» («The Bear»), «Дельта восени» («Delta Autumn»), «Зійди, Мойсею» («Go Down, Moses»).

Шість оповідань «Зійди, Мойсею» із вставною новелою «Ведмідь» зібрала в єдине ціле велика спільна ідея - стосунки між чорною і білою расами, а також роздуми про расові прокляття Півдня, про «духовну перспективу» розв’язання расових проблем у проекції морального змужніння особистості: «пошук правди, яка вища від усіх сил, що роз'єднують людське суспільство» [2, с. 9].

Саме ідея про рабство і виявляється в останньому оповіданні цього роману. Книга також названа як і негритянський релігійний гімн спірічуел (spiritual aмер.), на тему Виходу - другої книги з Біблії, це слова Бога до Мойсея; пряма паралель між рабством євреїв у Сгипті, де персонаж Моллі Бічем повторює, що іiі правнук був проданий фараону.

Цю ж тему можна простежити і в поемі «Мойсей» I. Франка, який 
прагнув не лише висловити свої погляди на минуле рідного народу «замученого» i «розбитого», а спрямувати його на активні дії, на здобуття людських прав. В образі Мойсея вождь, що самовіддано служить народові, любить його і присвячує себе боротьбі за його майбутнє.

Леся Українка також застосовує теми й образи світової літератури, розвиваючи новий жанр - драматичну поему. В одній із поем - тема вавилонського полону при аналогії полону України. Символічний зміст «I ти колись боролась, мов Ізраїль, Україно моя», де знаходимо такі рядки: «Чи довго ще, о Господи, чи довго ми ще будемо блукати i шукати рідного краю на своїй землі?» Становлять вони своєрідний ключ зрозуміння образу неволі як образу душі, раба власних стереотипів. Персонажі раби - це люди, які забули власне коріння.

Роман «Зійди, Мойсею» злютовує оповіді про «змішання» білих та чорних воєдино, щоб розрізнити реальність та вигадку, зобразити тілесне страждання і духовне бажання людини як суперечливу, не трансцендентальну версію історії. Роман досягає цього, критикуючи виплекані Фолкнером ідеї: описи ідентичності в листах, на надгробках, ідеалізація «іншого світу», білих жінок і чорношкірих партнерів. Постмодернізм Фолкнера у «Зійди, Мойсею» є результатом його здатності до самовдосконалення. Він ставить під сумнів основні принципи модерністичного, міфологізованого світу, який сам колись $\mathrm{i}$ створив.

У композиції роману відчутний зв'язок між модернізмом i постмодернізмом у творчості Фолкнера. Цей зв'язок закорінений певною мірою у спадковість. Саме в цих зв'язках можна вбачати істотну відмінність від контексту, у якому творилася така література. У дослідженнях американських літературознавців (Патріка О’Донела, Річарда Моріленда, Рамона Салдівара) зазначається, що саме здатність його літератури до протистояння, здатність порушувати або перевершувати правила Модернізму 3 великої літери або фолкнерівський модернізм - усе це робить його книги переконливими й досі актуальними. Фолкнер як постмодерніст - не просто «автор» чи «джерело робіт», а й, за висловом персонажа роману «Авесалом, Авесалом!», камінець, що, падаючи на поверхню води, породжує кільця, які ширшають аж до сусідньої водойми: нехай у цій водоймі інша температура, інший молекулярний рівень, але кільця від ๑) О. Б. Боднар, 2015. 
падіння каміння поширюються всією поверхнею води [2, с. 210]. Ці кільця, як фолкнерівська література, що охоплює модерн і постмодерн, рухаються в різному молекулярному середовищі історичних змін. Фолкнер, умовно, є поверхнею води, якою йдуть кільцеві розводи. Його тексти несуть не стільки авторські ідеї, скільки ix pyx через мінливий контекст його творів. Саме на цій межі у творчості письменника відбувається інтерференція модернізму й постмодернізму. Наприклад, у романі «Зійди, Мойсею» автор виклав думки персонажів так, що вони переосмислюються і випробовуються ним у наступних його романах. Як і Фолкнер, Джойс, Сйтс, Вулф створюють уявний замкнутий світ, що трансформує релігійний, політичний, культурний, виходячи 3 ніцшеанської концепції «відсутності Бога».

У творчості Валерія Шевчука знаходимо подібне суперечливе бажання визначити історичні та суб'єктивні процеси та зупинити їх рух, як i у В. Фолкнера. Український автор залучає читачів у замкнутий світ привида мертвого дому. У художньому часі однойменного роману цей образ з'єднує минуле 3 теперішнім, а через зближення часових полюсів вибудовується місток i в майбутнє. Фолкнерівська Йокнапатафа, Дублін у Джойса, Візантія у Єйтса, привид мертвого дому у Валерія Шевчука, Пакуль у Володимира Дрозда - це «лінгвістичні царства», розпорядником яких є митець як бог, що створює і населяє їх. У царині модернізму ці письменники намагалися змодифікувати світовий лад, відбитий у мові, щоб відкинути минуле. Їхня творчість спрямована на зародження нового «всесвіту». Успішність простору цього явища може пропагувати могутність митця (чи то перехід від минулого до сьогодення у Фолкнера, чи то деталізація у Джойса, чи то архетип дому в Шевчука, чи лакуна поліського краю у Дрозда). Ці мовні світи певним чином повторюють минуле, навіть якщо й намагаються звільнятися від нього. Вони служать минулій культурі, яка відкидає оновлення i прагне повернути себе «із ув'язнення». Персонажі в Йокнапатофі живуть у замкненому колі трагічних епізодів свого минулого, яке повторюється. Це повторення пережило покоління Сарторісів, Сатпенів, Компсонів на землі, проклятій рабством і війнами.

У Валерія Шевчука образ дому втілює складне єство людини, єдиний прихисток заблуканого у просторі мандрівника, а може й стати 
храмом людської душі. Ця суперечливість існує тому, що модернізм розглядають як спробу замінити старі уявлення і парадигми на нові у віртуальному просторі, який пересотворює попередні структури. Це багатовимірний процес модернізму, що постає як перехід від минулого до новаторства. Ці елементи, як у Фолкнера, так і у Сйтса, Вулф, Шевчука, Дрозда, уявнюються у вигляді кілець, що розходяться по воді. Фаталізм причин подій та їх наслідків у цих письменників завжди несподіваний. Важливо розплутати вузол складних зв'язків між спробою переступити через минуле i неминучістю його повторення.

У другій половині ХХ ст. Валерій Шевчук уносить у світову літературу свій досвід нової форми роману - роману в оповіданнях. «Привид мертвого дому» зацікавив літературознавців цілісною композицією, хоч до роману ввійшли оповідання, які письменник писав протягом 1986-2000 років. На думку Р. Мовчан, книжка «Привид мертвого дому» «нагадує вінок сонетів: останній акцент попереднього твору започатковуе тему наступного» [3, с. 15]. Як В. Фолкнер при творенні роману «Зійди, Мойсею», Валерій Шевчук, виявив схильність до монтування, складання воєдино окремих фрагментів, до творення викінченої художньої конструкції 3 поєднання різножанрових творів. М. Жулинський, М. Ільницький, Р. Корогодський, Р. Мовчан, М. Рябчук сходяться на думці, що твір нагадує «своєрідну барокову конструкцію».

Узірець такого специфічного авторського поводження зі своїм текстом спостерігаємо у В. Фолкнера в «Непереможених», а у Валерія Шевчука в романі-баладі «Дім на горі», що з'явися друком 1983 р., а створювався, починаючи із 1967 р., час від часу, у вигляді окремих оповідань. Основним i водночас цементуючим образом у фолкнерівських «Нездоланних» i «Зійди, Мойсею» $є$ внутрішній світ людини, а у Валерія Шевчука цим єднальним мотивом-образом у «Домі на горі» і в «Привиді мертвого дому» виступає архетип дому, який, власне, постає тим визначальним пунктом, що злютовує художній світ Валерія Шевчука. Варто зазначити, що «дім» для українського письменника $є$ втіленням самої людини, без чого вона не відбудеться, не реалізується на цій землі. Без усвідомлення цього дому неможливо осягнути суть людини. У різних часових просторах, під різним кутом зору письменник простежував надзвичайно складні ๑ С О. Б. Боднар, 2015. 
стосунки людини й дому. У «Привиді мертвого дому» розгалуження сюжету виписується в подібних межах, але увага автора зосереджена «на фатальній руйнації цих стосунків фіксації наслідків як притчовому резюме». Роман в оповіданнях Валерія Шевчука складається із п'яти VOX (голосів): VOX перший. «Привид мертвого дому», VOX другий. «Зачинені двері нашого «я», VOX третій. «Сім тітоньок великого музиканта», VOX четвертий. «Придивися до світу». VOX п'ятий. «Колапсоїд». Початок оповіді - однойменна частина «Привид мертвого дому». Уже в назві першого $\operatorname{VOX}(\mathrm{y})$ заховане ідейне навантаження всього роману: по-перше, головна психологічна дилема - минуле мертве, але воно може рухатися вслід за людиною i безпосередньо впливати на життя людини; по-друге, притчова ідея «мертвого дому» (суспільства, світу), який може зруйнувати, загубити душу людини, якщо момент імовірного спротиву буде втрачено. Герой-оповідач повертається в минуле через спогади про життя свого рідного дому.

Другий VOX «Зачинені двері нашого «я» (Історії зі сну)» відтворює своєрідну філософію індивідуальної пам’яті. Усі п’ять «історій»є ілюстраціями з минулого, яке має у просторі вимір, що уподібнюється снові; «зачинені двері нашого «я» - це вияв найсокровеннішого, найпотаємнішого, іноді підсвідомого, які для вселюдськості нічого не значать, але одноосібно можуть бути основою для змін навіть усього життя. Особливим варіантом мінімоделі мертвого дому як данини минулому $\epsilon$ VOX третій «Сім тітоньок великого музиканта». Узаємопов'язаність дійових осіб цього $\operatorname{VOX}(y)$ надзвичайно глибока, їх єднають спільні родинні зв'язки, які тримаються на існуванні старого дому і давнього саду. Тут також герой повертається у своє минуле, але воно ще існує реально - у вигляді дому в невеликому провінційному містечку, де живуть сім його тітоньок. Герой переконаний, що «рідний дім - це як гавань для втікача» [3, с. 287].

Семиструнна гама тітоньок виділяється яскраво в романі i найбільше запам'ятовується. В українській літературі на ідею такої побудови натрапляємо в Лесі Українки, відомий цикл пісень «Сім струн». Тут об'єднує пісні любов до рідного краю. У Шевчука спільний дім, що $є$ уособленням родини, сім'ї, яку об’єднує племінник. 
Логічним продовженням-триванням у романі в оповіданнях $\epsilon$ VOX четвертий «Придивися до світу». Перший розділ цього $\operatorname{VOX}(\mathrm{y})$ має екстравагантну символічну назву «Картина перша. Без рамки на голій стіні». Спогади героя про власне дитинство - основа розділу. Художньої довершеності цій житейській частині роману надає змальований образ хлопчика Толика, «що аж світився». Читач постійно відчуває теплий проникливий погляд самого автора, який без пафосних фраз надзвичайно любить людину, незважаючи на те, якою вона $\epsilon$, і з високості власного сумління й мудрості надає цьому химерному дійству справжньої художньої довершеності. Тому читач із головою поринає в цей витвір фантазії, незвичності побутописання Валерія Шевчука, зовсім забуваючи про ті екзистенційні ідеї, які $є$ наскрізними в цій повісті.

Автор пробує переконати читачів, що за зовнішньою маскою (рамкою) будь-чого, не лише людини, є ще внутрішнє, глибинне.

Толик, «хлопчик, що аж світиться» задумується над поняттям доброти, що може привести світ до гармонії. Ця ж думка про доброту стає продовженням другого розділу «Картина друга, зимова, 3 приміським лісом». Саме тема доброти єднає ці дві частини. У центрі оповіді - спосіб життя Анатолія Сиротюка, що певним чином поєднаний із долею героя-оповідача, який доводиться Анатолієві братом. Добротворча місія брата Анатолія, що розпочалася ще в дитинстві, триває досі й певним чином відбивається і на долі герояоповідача. Через реалістичний опис доль людей, картин життя, які у творі виконують роль необхідного тла, зароджується притчовий паросток про самоту й фатальну незахищеність людини, порятувати яку можуть найперше доброта і співчуття.

П'ятий VOX має назву «Колапсоїд». У завершальній частині роману «Привид мертвого дому» Валерій Шевчук пропонує, як і В. Фолкнер у романі «Зійди, Мойсею», своє бачення порозуміння людини зі світом. Водночас завершальна частина твору є своєрідним висновком у цій сповіді автора - художньому дослідженні міфу мертвого дому. Сюжет завершальної частини, на перший погляд, звичний. Герой отримує повідомлення від батька про знесення їхнього будинку. Він намагається усвідомити батькове повідомлення лише логічно: усе старе вже віджило своє і має поступитися новому. Однак «радості звільнення» герой не відчуває, натомість народжується ๑ О. Б. Боднар, 2015. 
гіркий розпач: так, як дім, «вмирає людина» в той час, коли розриває свої глибинні зв'язки зі світом. У цьому сенсі їх уособлює рідний дім, де ще мешкають батьки.

На відміну від попередніх VOX(iв), ця частина значно глибша i філософічніша. Герой розмірковує, прислухається до стану душі, який автор діагностує «дивним латинським словом collapses»- у душі оселяється тривога, самотність, нерішучість. За власним задумом письменник поділяе твір (Vox) на кілька частин, де 3 різних боків обстежує наростання колапсичного стану героя. Душевна пастка звужується, до зруйнованого дому додається повідомлення про звільнення героя з роботи, зустріч із колишньою дружиною.

Варто зауважити, що п'ятий VOX створювався в 70-ті роки, коли письменник відтворив і власний досвід життя. Та все-таки читати цей твір конкретно-історично немає сенсу, адже Валерій Шевчук належить до тих митців, які створюють такі умови, аби читачі побачили його твір поза часом і соціумом (як і його герой раптом побачив свою стару вчительку «не ковачем наших бідних дитячих душ під шаблони», а як звичайну людину, у поношених черевиках $\mathrm{i}$ простих панчохах), крізь призму людських проблем.

Як уважає Р. Мовчан, «ця частина тим і прикметна, що в ній важливими $є$ не стільки роздуми-версії про причини колапсу, як психологічно точно, через сюрреалістичні візії, сновидіння передано відчуття персонажа у процесі поступового завмирання, утрати свого первісно енергетичного єства, розчинення у світі змертвілому, колапсоїдному» [3, с. 25].

Отже, жанровий різновид роману в оповіданнях дав змогу обом прозаїкам розгортати оповідь фрагментами, що потім у міру дальшого накопичення матеріалу, усвідомлюються як частини більшого цілого i, єднаючись у ньому, витворюють мозаїчну картину романного цілого, також остаточно не завершенного, відкритого i для нових доповнень, продовжень, i для свіжих прочитань і тлумачень.

\section{Лiтература}

1. Доценко Р. Дещо про стиль Фолкнера : [післямова] / Р. Доценко // Крадії та інші твори : пер. з англ. / В. Фолкнер. - К. : Дніпро, 1972. - 510 с.

2. Шевчук В. О. Привид мертвого дому : [роман-квінтет] / В. О. Шевчук ; [передм. Р. Мовчан]. - К. : Унів. вид-во ПУЛЬСАРИ, 2005. - 600 с.

3. Фолкнер У. Статьи, речи, интервью, письма / Уильям Фолкнер; сост. 
А. Н. Николюкин ; [пер. О. Сороки, Ю. Палиевской, С. Белова]. - М. : Радуга, 1985. - 488c. 4. Cambridge Companion to William Faulkner / ed. Philip M. Weinstein. Cambridge : Cambridge University Press. - 1995. - 236 p.

Стаття надійшла до редакиї̈ 24.12.2014 p. 